\title{
Impact of digital tools on the research writing process : A case study of collaborative writing in computer science
}

\section{Hynninen, Niina}

2018-08

Hynninen, N 2018 , ' Impact of digital tools on the research writing process : A case study of collaborative writing in computer science ' , Discourse, Context \& Media , vol. 24 , pp. 16-23 . https://doi.org/10.1016/j.dcm.2018.01.005

http://hdl.handle.net/10138/313893

https://doi.org/10.1016/j.dcm.2018.01.005

cc_by_nc_nd

acceptedVersion

Downloaded from Helda, University of Helsinki institutional repository.

This is an electronic reprint of the original article.

This reprint may differ from the original in pagination and typographic detail.

Please cite the original version. 
Final draft of:

Hynninen, Niina (in press / 2018) Impact of digital tools on the research writing process: A case study of collaborative writing in computer science. Discourse, Context and M edia. Special issue edited by M aria Kuteeva and Anna M auranen. https://doi.org/10.1016/j.dcm.2018.01.005.

\title{
Impact of digital tools on the research writing process: A case study of collaborative writing in computer science
}

\author{
Niina Hynninen (University of Helsinki)
}

\begin{abstract}
This paper reports on a case study on collaborative research writing in computer science, with particular focus on the researchers' use of digital writing and social media tools. The research paper is still a prominent genre in the field, but technological advances such as the development of realtime collaborative writing tools and social media have created new opportunities for collaboration as well as the sharing of research results. This paper takes a closer look at how digital tools, particularly collaborative writing tools and Twitter, are utilised in the process of producing a research paper for publication, and how the authors and their colleagues view the role of such tools in the text production process. The data include a text history of a research paper, as well as research interviews with the main authors and their colleagues. The data have been approached from a local practices perspective, considering the paper as part of the writing practices of the multicultural research group where the authors worked. The interviews provide further perspectives on the researchers' use of digital tools. The findings shed light on collaborative research writing practices, particularly how collaborative writing tools, which enable new practices such as synchronous writing, may not be utilised by the researchers in the ways intended by the developers. The findings also highlight the significance of social media tools, particularly Twitter, in post-publication activities, with important implications for researcher education.
\end{abstract}

Keywords: collaborative writing, writing practices, text history, text trajectory, digital media, twitter

\section{Introduction}

Academic publications may serve as a measure of individual accomplishment, but academic text production is a networked activity (see Lillis \& Curry 2010; Belcher, Barron Serrano \& Yang 2016). Particularly, writing for publication relies on a range of different actors (e.g. peer reviewers, proofreaders) who influence the text production but who may not have an 'authoring' role in the traditional sense. These various 'literacy brokers' (Lillis \& Curry 2010) are relevant for all research writers, but perhaps even more so for those writing in their L2 (see e.g. Flowerdew 2008). This paper aims to shed light on this networked, social nature of text production by focusing on the 'text history' (Lillis \& Curry 2010) of a research paper written by a team of computer scientists to be presented at an international conference. My focus, in particular, is on the role of digital writing and social media tools in the networked text production.

While the research paper has been a popular research topic, much of the research conducted on this genre has either dealt with the finished product (e.g. Samraj 2005; Lin \& Evans 2012), or specific aspects of the text production trajectory, particularly different brokering activities (e.g. Flowerdew 2001; M ur-Dueñas 2013; Lillis \& Curry 2015). M uch of the research on literacy brokers has been concerned with the Englishmedium writing of L2 English users (for the term 'L2 user', see Mauranen 2012), and what role the brokering plays in shaping their writing for publication. These studies often approach writing as a trajectory, highlighting the social nature of academic text production (e.g. M ur-Dueñas 2013; Lillis \& Curry 2015), but collaborative writing is typically not a concern for them. 
Research that sets out to address issues related to collaborative writing in academia, then again, has tended to focus on student writing (e.g. Bremner et al. 2014; papers in Van Steendam 2016), often from a language learning perspective (e.g. Shehadeh 2011; Storch 2005, 2013). Some work, though, has been conducted particularly from the perspective of novice academics. For instance, Li's (2006) work sheds light on a physics PhD student's publication-navigation process, and Armstrong (2015) focuses on the role of peer feedback in the research paper writing of a PhD student in computer science. In addition, Gimenez and Thondala (2012), with both students and professionals as study participants, provide empirical evidence for collaborative writing practices in engineering. However, professional academics' collaborative writing practices in general have received relatively little attention. In fact, it has been stated that "publication practices within research groups are still under-examined" (Belcher et al. 2016: 510; see also Van Steendam 2016). With this study, I seek to provide some answers to what these practices may be like.

A notable exception to the limited attention on professional academics' colloborative writing practices is M cGrath's (2013) study on the online co-authoring of a research article in pure mathematics. M cGrath's research is important not only in its focus on collaborative writing, but also in that it highlights the effects that digital tools, in this case an open-access research blog that enables the participation of professional mathematicians and non-specialists alike, may have on research writing practices. In general, "academic writing has been reshaped in many ways with the rise of new technologies" (Barton \& Lee 2013: 2 ), and research is being conducted on the changing writing practices of contemporary academics also from the perspective of digital media use (e.g. Tusting et al. 2017). New genres and forms of writing have become relevant for researchers, among those blogging (see e.g. M auranen 2013; M yers 2010, 2013), tweeting (see e.g. Gillen \& M erchant 2013) and wikis (see e.g. M yers 2010; for an overview of all three, see Kuteeva 2016), and for instance, Barton (2015) has considered the centrality of technology in contemporary academic writing practices.

However, questions still remain in terms of what roles digital tools play in the still prominent research paper writing for publication (see Belcher et al. 2016), particularly considering the full trajectory of the produced text and the steps writers take in planning, drafting, evaluating and advertising their research papers. The questions I seek answers to in this paper are:

1. In what ways are digital writing and social media tools utilised in the writing of a research paper for publication?

2. How do researchers view the role of such tools in the text production process?

To answer these questions, I explore the trajectory of a particular research paper written by a team of computer scientists, and analyse research interviews with the authors and their colleagues from the same field regarding their use of digital tools, particularly collaborative writing tools and Twitter, in their research writing.

The findings shed light on the use of different digital tools for academic text production. While the end-product may be in more or less the same recognisable format of the research paper, there is more that goes into the writing, evaluating and advertising of the paper that digital tools enable, and possibly compel, scholars to do. The paper suggests that even if the research paper genre seems to be 'intact' - for now, at least (cf. Pérez-Llantada 2013) - digital tools influence the writing process and particularly what happens after the paper has been accepted. The promotional aspect is central in making (or at least attempting to make) a research group's work heard in a world of high-speed publishing, where publications from two years back may be old. This is an important aspect to take into account in engaging novice scholars into academia, that they are made aware of different aspects of academic text production and what it makes to increase chances of being heard and read in their field.

\section{Collaborative writing practices}

Various terms have been used in previous research to refer to writing in teams. The most common one, also adopted in this paper, seems to be collaborative writing (e.g. Ede \& Lunsford 1990, 2012; Forman 1992; Lowry et al. 2004), but terms such as collaborative or joint authoring (Newman \& Newman 1992), 
cooperative writing (O'Donnell et al. 1985) and group writing (Gere 1987; Ede \& Lunsford 1990) have also been used (for a fuller list of terms used, see Lowry et al. 2004).

Conceptualisations of collaborative writing similarly vary. Collaborative writing may either be understood in a narrow sense of writers producing a text 'together', whether face-to-face or online, or in a broader sense as the kind of writing that includes the participation of others. An example of the latter type of definition is provided by Van Steendam (2016: 186) who defines collaborative writing as "the participation of others, predominantly peers, in the writing process (any phase) possibly but not necessarily leading to a joint final written product" (cf. Klein 2015; see also Bremner et al. 2014). This definition highlights the nature of writing as a networked activity, but at the same time it seems to understate the role of the writers. The writers' role is more pronounced in the more narrow definitions of colloborative writing (e.g. Lunsford \& Ede 1990, 2012; Lowry et al. 2004; Gimenez \& Thondlana 2012), which is why I define collaborative writing in this study following Gimenez and Thondlana (2012: 473) as "a social activity by a team of people working towards producing a common document". This definition means that collaborative writing is treated as "an iterative and social process that involves a team focused on a common objective that negotiates, coordinates, and communicates during the creation of a common document" (Lowry et al. 2004: 72).

The collaborativeness of the writing thus lies in the joint text production, that is, the act of writing a common document, as well as in the social processes that are fundamental to task completion (Gimenez \& Thondlana 2012). What is important to note, then, is that collaborative writing includes also other activities than the actual writing of the text, that is, in addition to various writing activities (e.g. planning, drafting and revising), a number of social activities are needed to organise the writing (e.g. discussing team composition and allocating roles), and supporting activities (e.g. consulting others) are also central (Gimenez \& Thondlana 2012).

In creating a taxonomy of the processes and components of collaborative writing, Lowry et al. (2004) also draw attention to document control modes (e.g. collaborative writing software), team roles (e.g. coauthor, reviewer) and work modes (i.e. how physically close the team is, and when the team members write), as well as the team's writing strategies, or their approaches for coordinating the writing. These strategies include group single-author writing, sequential writing, parallel writing (incl. horizontal-division writing and stratified-division writing) and reactive writing (Lowry et al. 2004). In single-author writing, one person writes the text on behalf of a group of people. In sequential writing, one person writes at a given time and then passes on the text to the next person. In parallel writing, multiple authors work on the text in parallel. The writing may be divided so that each participant is responsible for a particular section (horizontal-division) or so that each participant takes a particular role in the text production process (stratified-division). In reactive writing, text production occurs in real time, with authors reacting and adjusting to each other's writing. It is likely that these strategies and thus also the different writing and social activities vary depending on the task at hand, and in fact, collaborative writing has been described in empirical research as "a cyclical process" where the same writing activities may recur several times (Gimenez \& Thondlana 2012).

In tracing the trajectory of a research paper in this study, I draw on the taxonomy created by Lowry et al. (2004) to the extent that I consider the different processes and components of collaborative writing as described in the (largely theoretical) taxonomy in relation to empirical data. The study contributes to empirical research on collaborative research writing practices, with particular focus on professional researchers rather than students. I draw on the sociolinguistics of writing (e.g. Lillis 2013; Lillis \& M cKinney 2013) and approach writing as a social practice (e.g. Barton 2007), that is, I treat writing as a situated process influenced by different factors and brokers at different stages in the course of text production. I pay attention to what people do in particular localities and the meanings they ascribe to their activities. Such an approach is key in understanding the social nature of collaborative writing.

\section{Material and Methods}

Two sets of data have been used in this paper: (a) a text history of an English-medium research paper written in the field of computer science, including research interviews with the three main authors of the 
paper (twice with W1, once with W2 and W3), and (b) research interviews with their colleagues (\#10), also including colleagues in other subfields of computer science. The text history in focus provides an example case of a text production process and the use of digital writing and social media tools during the process, and the interview data make it possible to broaden the perspective beyond the particular case. The data have been summarised in Table 1.

\section{Table 1. Example text history and interview data}

Text history of an English-medium research paper, incl. interviews with the authors:

- $\quad$ research interviews (partly text-based) with the three main authors (W1-W3), twice with W1

- audio-recordings and observations of W3's research group's writing clinics

- several manuscript drafts

- $\quad$ proofreader corrections before submission and camera-ready version, and interview (via email)

- $\quad$ peer reviews and rebuttal

- video-recording of rehearsal presentation, final conference presentation slides

- $\quad$ press release (in Finnish and English)

- related twitter comments (by W2 and W3) and website contents

- document data such as conference submission and writing guidelines

Interviews with members of W3's research group (\#5) and colleagues in a neighbouring university (\#5)

The study participants were mainly from the more applied side of computer science, along with those working in human computer interaction, or $\mathrm{HCl}$, which means that not all the study participants had an educational background in computer science, but rather in cognitive science, mathematics, or other disciplines.

The research paper in focus lists six authors, but only the first three, who were active in writing the paper, have been included as study participants. The authors, all with a PhD degree, were L2 users of English working in two different universities, one in Finland and one in an Asian country. All the authors were male. The first author (W1) was the lead author. The second author (W2) was described by W1 as having a "supportive" role, that is, he was asked to write specific parts of the paper. The third author (W 3) was the leader of the Finnish research group, and he was described by W 1 as having a "guiding" role, that is, he would, for instance, suggest how to frame the research, but also how to express things. The rest of the named authors (three researchers from the Asian university) participated in conducting the study reported in the paper, but were described as having a very minor, or no role at all, in the text production process. The interviews with the three main authors were conducted around the start of the text production process (first interview with W1 and interview with W3) and after the camera-ready version had been submitted (second interview with W1 and interview with W2).

The 10 interviewed colleagues were mainly L2 users of English, although two L1 speakers of English were also interviewed. ${ }^{1}$ The colleagues were in different career stages, with some studying for their PhD, others working as postdocs, senior scholars/lecturers or professors. The colleagues all worked in Finland during the time of the interview, either in W3's research group or at another university in Finland. Five of the interviewed colleagues were female and five male. The interviews with W3's research group members were conducted either slightly before or around the time of the writing clinics (i.e. before first submission). These colleagues were writing papers for the same conference that the authors of the example paper, and they thus share at least some of the experiences of the authors. The interviews with the colleagues from another university have been included to broaden the focus beyond the one research group.

Informed consent was obtained from all study participants. All interviews, conducted in either Finnish or English, were audio-recorded and transcribed (for transcription conventions, see supplementary

\footnotetext{
${ }^{1}$ The 13 interviewed researchers (i.e. the three authors and their colleagues) had eight different L1s, not listed here for anonymity purposes.
} 
materials). I have translated excerpts from the interviews conducted in Finnish into English, with the intention of including features such as repetitions and unfinished utterances so that the translations would resemble the style of the original as closely as possible. The original Finnish transcriptions are available as supplementary material. All the data have been collected for the purposes of a research project entitled Language Regulation in Academia (LaRA) ${ }^{2}$ at the University of Helsinki during the years 2016-2017.

The data have been examined to trace the trajectory of the research paper, particularly paying attention to the events when digital tools were engaged in the writing. In line with social practice approaches to writing (e.g. Barton 2007; Lillis 2013), my purpose is to highlight the situated nature of writing, which seems to be ignored in, for instance, Lowry et al.'s (2004) taxonomy of writing. I will, however, also discuss the authors' use of digital tools in relation to the processes and components of collaborative writing as described in Lowry et al.'s (2004) taxonomy, that is, I will consider participant roles, particularly those of the three main authors; the activities along the text trajectory, particularly in relation to the digital tools used by the authors; document control modes and work modes used; as well as the writing strategies adopted by the authors. This is done in order to consider the applicability of the taxonomy to empirical data. When discussing these issues, I also refer to the research interviews I have conducted with other researchers in the field in order to broaden the perspective.

The interviews with the three main authors and their colleagues working in the Finnish research lab have been used to further investigate the researchers' use of and views about digital tools, and comparisons have have been made to interview data from colleagues in other subfields of computer science, also working in the Finnish context. The interviews had a broader focus on writing practices, and were thus first searched for those parts where digital tools were talked about, and these parts were then analysed in more detail to see what digital tools researchers report to use and for what purposes, and what role they give to these tools in their research writing. The data has been treated as representing insider accounts about the use of digital tools, but also as indexing specific discourses about writing (see Lillis 2008).

\section{Findings}

\subsection{Trajectory of a research paper}

Collaborative writing is the norm in the field of computer science (see e.g. Puuska \& M iettinen 2008), and unlike in many other fields, conference proceedings are highly valued. A presentation at a conference requires submitting a full paper for peer review; for the most prestigious conferences, less than a fourth or fifth of these submissions are accepted. The research paper discussed in this study was written and accepted for presentation at such a prestigious conference. The authors and their colleagues described this conference as one of the key conferences in their sub-field, and they targeted it each year. In the words of C7: "everyone does $X^{3}$ you have to do X which is the big big big one". In fact, the rhythm of the academic year very much seemed to evolve around preparations for this conference (cf. Ochs and Jabocy 1997).

The trajectory of the paper, along with the use of digital tools in the writing process, is given in Table 2. In broad terms, the trajectory followed a path typical of peer reviewed papers where several brokers were involved in the text production process (see e.g. Lillis \& Curry 2010). The writing in the research group was organised around so called writing clinics where the research group members and also colleagues outside the research group met face-to-face to discuss drafts of their manuscripts targeted to the specific conference. Once nearly ready for submission, the paper was sent for proofreading to a language professional, after which it was still slightly modified. The paper was then submitted for peer review. Once reviewed, the authors wrote a rebuttal to the reviewers describing the changes they would make to the paper and started working on the revisions. Based on the rebuttal, the paper was accepted for publication. The authors then finalised the paper, and before submitting the final version, also sent the paper for

\footnotetext{
${ }^{2}$ The LaRA project is directed by Prof. Anna Solin and funded by the Kone Foundation. The project website is at: http:// www.helsinki.fi/project/lara.

${ }^{3}$ " $\mathrm{X}$ " is my anonymisation of the name of the conference.
} 
proofreading to the same language professional they used earlier on in the process. Once the paper was finished, the authors started preparing their conference presentation. What is particularly notable is the heavy advertising of the paper, the conference presentation, and the research group more generally, via social media.

Table 2. Use of digital writing and social media tools in the process of writing a research paper

Date

\section{Setting and use of cigital tools}

\begin{tabular}{|l|l|}
\hline M ay & $\begin{array}{l}\text { Research group leader (W3*) starts Slack: requests group members to suggest titles and } \\
\text { then to start writing abstracts }\end{array}$ \\
\hline 10 June & Writing clinic 1 (titles and abstracts: distributed to colleagues via email prior to meeting) \\
\hline 20 June & Writing clinic 2 (titles and abstracts: distributed to collegues via email prior to meeting) \\
\hline & W1 starts Overleaf, uses conference LaTeX template \\
\hline 22 July & W1 sends email to co-authors (W2-W6) with link to Overleaf and distribution of work \\
\hline 3 Aug & $\begin{array}{l}\text { Writing clinic 3 (titles, abstracts and introductions: distributed to colleagues via email } \\
\text { prior to meeting) }\end{array}$ \\
\hline 24 Aug & Writing clinic 4 ('whole' drafts: texts distributed to colleagues via email prior to meeting) \\
\hline 7 Sept & Writing clinic 5 ('whole' drafts: distributed to colleagues via email prior to meeting) \\
\hline Sept & $1^{\text {st proofreading by language professional (email communication, LaTeX files) }}$ \\
\hline Comment round among all authors, as well as discussions and last check with printout by \\
the main authors (W 1, W2 and W3)
\end{tabular}

* The authors of the research paper in focus are referred to as W $1-W 6$ in the order that their names appeared in the final version of the paper.

The trajectory in Table 2 illustrates the various roles the main authors had in the text production process (i.e. not only co-author, but also commentator, presenter, tweeter etc.) and importantly, it highlights the multitude of writing, and speaking, that is done 'around' the paper (cf. Ochs \& Jacoby's 1997 study on a group of physicists conversing to put together a presentation). In terms of the text production, various digital tools were used alongside those needed for the actual writing of the paper, which for the most part took place in Overleaf, a cloud-based collaborative writing programme. Based on the research interviews and my observations, digital writing and social media tools were used for different purposes depending on the activity along the text trajectory, as well as individual preferences. The purposes can be summarised as follows:

(a) to organise writing in the research group (W3 in his role as the research group leader): a team collaboration tool called Slack was used, although invitations to writing clinics and the drafts discussed in the clinics were sent via email by a group member after a suitable date had been arranged using Doodle 
(b) to actually write the research paper: the study participants reported various practices, which, as in the example case, often involved using a real-time collaborative writing tool, such as Overleaf, but could also be a combination of sending Word files per email or using different version control systems, such as Git (see section 4.2.); the document template from the conference website was used, and the study participants also reported to use, for instance, the microblogging tool Twitter to find relevant research literature (see section 4.3.)

(c) to communicate with people involved in the writing and evaluating of the paper: email was the primary means of communication, but the study participants also reported using, for instance, Skype for video conferencing, and the conference submission system was used when submitting manuscripts

(d) to communicate about the results and achievements of the research group members: for this particular paper, the authors used a combination of Twitter (see section 4.3.) and websites where they posted the full paper, the conference presentation slides and also a press release 4

To consider these purposes in more detail, I will now turn to a more detailed analysis of two of the digital tools that seem to be shaping the computer scientists' research writing practices the most, that is, real-time collaborative writing tools and Twitter.

\subsection{Collaborative writing tools}

The study participants reported using various document control modes for collaborative writing, including collaborative writing software, different version control systems and file depositories, and simply sending Word documents back and forth via email. Collaborative writing tools tended to be described as the better option, and the practice of using email for sharing files as "need[ing] to change" (C7). Change was also acknowledged on a more general level as one of the researchers suggested that "these are the main tools we use today next week there may be others" $\left(\mathrm{C}^{2} \mathrm{t}^{5}\right)$. The choice of the mode was typically attributed to the first author, which further means that writers need to adjust to different modes: "well it depends who I'm working with, and it depends who the lead author is that, um, because they tend to decide how things are going to be shared so" (C7).

For the example paper in focus in this study, a collaborative writing tool called Overleaf was used as the document control mode. This choice made it possible for the authors to write at the same time even if they were in different locations. In practice, however, W1 asked W2, W 4 and W5 to focus on specific tasks or sections of the paper and $W 3$ and W6, the more senior researchers, to comment on the text. This means that the writing was mainly done in parallel, but interestingly combining horizontal- and stratified-division writing, that is, different people were asked to work on specific sections or to perform particular roles. In the words of W1t: "we have shared the link \{to our manuscript in the Overleaf system \} with our group of researchers and agreed which sections each and everyone is responsible for and then we go and produce text there as agreed". Writing together in real-time using Overleaf reportedly only took place while doing final revisions before submission, which implies that some reactive writing also took place. As is illustrated in Example 1, though, even the very last revisions were divided among the authors so that everyone knew what they were responsible for adjusting.

\section{Example 1}

W1: ((...)) we did agree on who would edit when $\triangleleft$ : right yeah okay $>$ so apart from like in the end on the last day $\triangleleft$ : yeah $>$ it could be so that several people $\triangleleft$ : yeah $>$ revised it simultaneously $\triangleleft$ : [yeah] > [but] there too we had agreed on who revises what like someone $\triangleleft$ : right $>$ works on tables and someone $\triangleleft$ : yeah> proofreads the text

\footnotetext{
${ }^{4}$ All of the texts produced as part of the trajectory of the paper were in English, apart from the press release which was also published in Finnish.

${ }^{5}$ The ' $t$ ' after the speaker code means that the utterance has been translated from Finnish.
} 
Also other researchers reported that even if they used real-time collaborative writing tools, it was typical to divide the writing task, as described in Example 2.

\section{Example 2}

C10: yeah so usually i think even though in theory i guess those systems would allow that you write at the same time on different parts we're never trusting that really $\varangle$ : $\mathrm{mhm}>$ so it's more like sharing er distributing the work you're [writing] $\triangleleft$ : [mhm-hm] $>$ this paragraph $\triangleleft$ : right $>$ you're writing that section and now don't do anything i'm [writing on that part] $\varangle$ : [yeah okay] >um you can later have a look at it [or] $\triangleleft$ : [okay]> um $((\ldots))$

It thus seems that even if the real-time collaborative writing tools enable synchronous writing, in practice, writers may prefer to work asynchronously (see Scheliga 2015), even if they were using the system for sharing and distributing their work. Part of the reason may of course be to simply share the workload and make sure that each co-author knows what they are supposed to contribute (see Example 1), but also other reasons for this choice were given in the interviews. These included, for instance, technical difficulties, as illustrated in Example 3 and also alluded to in Example 2 above (never trusting that really).

\section{Example 3}

W3: ((...)) this \{i.e. Overleaf $\}$ is good otherwise but er, if someone does something at the same time like you are for instance editing here and someone is [there] $\triangleleft$ : [yeah] >above you your text @jumps@ downwards all the time $\triangleleft$ : ah [@okay@ okay] $>$ [(yeah) that]'s annoying so so this management of real-time writing is a [problem otherwise this is really very smart] $\triangleleft$ : [okay right yeah yeah yeah] > but th- this too can be solved so that these are divided into different files so that everyone works in their own file $\triangleleft$ : ah>then it is okay $\triangleleft$ : okay right yeah yeah>

(translated from Finnish)

Writers may also be reluctant to share draft versions of their texts, as suggested in Example 4:

\section{Example 4}

CS9: ((...)) you don't always want feedback on your on your (int-) I mean $\triangleleft$ : mhm>you're not writing things er perfectly in your first draft so $\triangleleft$ : yeah>you don't you don't necessarily want feedback on on what could be a draft or a version of a section so there's also the fact that you might decide to work separately and then [input] $\triangleleft$ : [yeah yeah] >this new paragraph [or this edited paragraph to the to the] $\varangle$ : [right yeah yeah] $>$ to the overleaf $\triangleleft$ : yeah [yeah] $>[\mathrm{er}$ repository] so $((\ldots))$

In all, it seems that how collaborative writing tools are used depends on practical reasons related to individual preferences and how well the collaborative writing software works. In terms of writing strategies (see Lowry et al. 2004), the tools enable reactive writing, but at least the writing of the example paper seemed to mostly rely on different forms of parallel writing. In general, the writing strategies varied during the course of the text production and particularly from one writing task (and genre) to another (e.g. W1 single-authoring the rebuttal), which means that it is not possible to talk about one specific strategy. The findings thus suggest that such abstract strategies may be too rigid to describe the actual practices of writing, and that it would make more sense to focus on author and other participant roles that highlight the cyclical nature of writing (see Gimenez \& Thondlana 2012) and the influence of all these different actors on the text production and its product(s). 


\subsection{Twitter}

A variety of different digital tools were mentioned in the interviews as supporting the research and research writing processes (e.g. project wikipages and Slack, collaborative writing software and version control systems, Skype, coding-support websites, research blogs, Twitter and SlideShare, project websites and sites for sharing research publications). Email was typically described as the most important tool for communication; one researcher even stated that "email is the most important tool for my work" (C4). $M$ any also emphasised the increasing importance of social media, particularly Twitter; in the words of W3, "Twitter is extremely important". In fact, 9 out of the 13 study participants reported to use Twitter for their research either actively or at least to some extent (cf. Fransman 2013). As to the main authors of the paper in focus, W1 reported not to have a social media presence, whereas W2 used Twitter to some extent, and W3 was an active tweeter. Facebook was often mentioned in the interviews, but reportedly mainly used for private communication, whereas research blogs were said to be used to communicate about research projects (C3) and to find out about how to write a specific kind of genre, such as a rebuttal (C1). Considering the central role that Twitter received in the interviews but also in the example text trajectory (despite the fact that W1 reported not to be on Twitter), I now turn to researcher comments on the role of Twitter in their research practices.

Those researchers who used Twitter, reported to use it for a number of different functions:

- to find and share research-related resources

- to make public announcements re: activities going on in the research group

- to share 'interesting' and 'cool' stuff

- to make new contacts

Example 5 below from my interview data illustrates the multiplicity of functions individual researchers reported to use Twitter for.

\section{Example 5}

C10: yeah i have a twitter account mainly for for science-related things research-related things uh and that $i$ of course then i'll also use to promote my own work $\triangleleft: \mathrm{mm}>$ if $i$ publish a paper or $\triangleleft: \mathrm{mhm}$-hm > if we publish a press release or something like that then we we um announce that over twitter $\triangleleft:$ mhm okay> um yeah

I: $\quad$ so it's kind of an advertisement

C10: $\mathrm{mm}$ yeah

I: $\quad$ that kind of use @ @

C10: yeah yeah $\varangle$ : yeah [yeah] $>$ [but also] yeah i also use it as as a, information [tool] $\triangleleft$ : [mhm] $>$ for myself to get $\triangleleft$ : okay > to gather information what [have] $\triangleleft$ : [right]>others have been doing $\triangleleft$ : [okay] $>$ [what] new cool thing is out there $\triangleleft$ : okay $>$ in terms of of research or or systems or technology or $\triangleleft$ : okay $>$ things like that $\triangleleft$ : $\mathrm{mhm}$-hm>yeah

In the example, the researcher first specifies that her Twitter use is mainly for research-related purposes, after which she goes on to explain what she uses it for. It can be seen that for this researcher, Twitter is a tool to both stay alert on what is going on in the field (gather information) and to promote her own research (of course then i'll also use to promote my own work). Her reference to new cool thing[s] also suggests that Twitter may be used as a kind of diversion from the 'actual' research work. In line with Myers (2013; see also Gillen \& Merchant 2013), it thus seems that Twitter can provide insights into the everyday practices of scholars beyond merely reporting about one's achievements.

Example 6 below similarly illustrates how Twitter has been adopted for work-related purposes.

\section{Example 6}


$\mathrm{Cl}$ : yeah twitter $\mathrm{i} i$ follow it and i use it quite a lot er to post anything $\varangle$ : [mhm-hm] $>$ [particula-] i mean i only post about this er stuff related to work kind of like publications $\triangleleft: \mathbf{m h m}-\mathbf{h m}>$ or if there's a talk here $\varangle: \mathrm{mhm}$-hm>i post about it if $\mathrm{i}$ follow some- if $\mathrm{i}$ notice something interesting $i$ re- retweet it so and the activities that are going on in our group if something interesting someone is visiting us $\triangleleft$ : $\mathrm{mhm}$-hm>or someone visited us er we would post there [so] $\triangleleft:[\mathrm{mhm}-\mathrm{hm}]>$ so yeah and we use twitter er i use twitter quite quite a lot yeah

In this example, the researcher focuses on the promotional aspect of Twitter, also highlighting the role of Twitter in sharing about research group activities on a broader scale. What is notable in both of the examples ( 5 and 6 ) is the way that the researchers switch between the first person singular I and the first person plural we forms in describing their use of Twitter (in Example 5: i'll also use it, we um announce that and in Example 6: i post, i retweet, we would post), which on the one hand, highlights the social nature of Twitter, and on the other hand, reflects the centrality of the tool in promoting the activities of the research group, and individuals within those groups. The importance of Twitter in sharing ideas is also evident in Example 7, where the researcher reports of new contacts she has made through this platform:

\section{Example 7}

C7: i've ended up getting to conversations with people who i would never meet otherwise $\triangleleft$ : mhm-hm>really like or i would be too scared to go and to talk to them at a [conference] $\triangleleft$ : [mhm-hm]>or whatever $\triangleleft:$ okay> um and then there's ended up being projects that have started [because of] $\triangleleft$ : [oh okay] $>$ of these things $((\ldots))$

As illustrated in Examples 5-7, the researchers described Twitter as beneficial for themselves. In addition, particularly two of the senior scholars I interviewed (W3 and C3, a colleague from a neighbouring university) raised other aspects related to navigating the world of social media. One was a very active tweeter and social media user (W3), the other only gradually getting into it (C3). Both scholars had their own research groups, and both emphasised the importance of social media in increasing the visibility of their research groups' achievements. Example 8 provides an example of how W3 reported to use Twitter to promote his own and his research group's activities, and how the use of Twitter also ties in with other (digital) media he reported to use to promote the research both within and beyond the academic community (see also the text trajectory in section 4.1.).

\section{Example 8}

W3: ((...)) so let's say that if i give a talk $\varangle$ : yeah>so then i of course before the talk i post fon twitter \}that $\mathrm{i}$ am going to give a talk $<$ : yeah $>$ and raise expectations then $\mathrm{i}$ give the talk and at the same moment $\varangle$ : yeah $>i$ publish my slides on slideshare which is also kind of [social media] $\triangleleft$ : [okay right] $>$ then i get people to watch it like hundreds of people to [watch it even if they haven't been there in the talk] $\triangleleft$ : [yeah right yeah] >and er similarly when a paper comes out then $\triangleleft$ : yeah $>$ we always publish always like in social media and then $\triangleleft$ : yeah>in the press reports and stuff $\triangleleft$ : okay $>\mathbf{s o}$ it's a really important part $\varangle$ : okay $>$ of this this job if we didn't do this then probably the attention we would get for this work would be [much

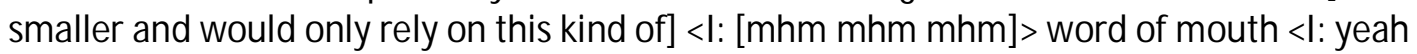
yeah > and of course it is possible to do it that way as well but then it there are two aspects to it on the one hand that we like get the attention of those people who are supposed to see our work and the other thing is such that we of course have societal responsibility that we do a lot of such work that interests people ((...)) 
What this example suggests is that promoting one's research in social media has become an integral part of the research group's activities. Posting about academic activities on Twitter and related fora is described as a self-evident (of course...i post, see also example 3) and recurrent (we always publish always like in social media) practice. Also the text trajectory discussed in section 4.1. points to this direction: the research paper was promoted via Twitter; a project website was created on the basis of the paper; and a press release was published in English and Finnish, which suggests addressing different audiences. To take a closer look at W3's twitter feed related to the research paper, the feed shows first of all that W3 tweeted about the success of his research group: first in December, once the decisions were out, and then in February to rejoice the group's success in the Best Paper Awards, this time with a link to the abstracts of the papers. In February, he also focused on the particular research paper, tweeting a direct link to the full paper; in May, before the conference, he advertised the time and place of the conference presentation, again with a direct link to the paper; and finally in the conference, he tweeted a photo of the presention. For this researcher and his research group, Twitter thus plays a central role in their research practices.

The emphasis on also reaching stakeholders and the general public, and not only the "people who are supposed to see our work", that is, colleagues working in the field, is evident in Example 9, although this researcher was not an as experienced social media user as the previous one.

\section{Example 9}

C3: $((\ldots)))$ this is the idea $\triangleleft$ : yeah>idea behind this $\triangleleft$ : yeah $>$ that we could also offer it fi.e. our work \} in some such place place that well which which would perhaps find these $\triangleleft$ : right> some company representatives ((...)) now that we because of this set up our group's own $\triangleleft$ : $\mathrm{mhm}-\mathrm{hm}>$ twitter account so $\triangleleft$ : yeah $>$ we only post $\triangleleft$ : right $>$ stuff like related to our group there $\triangleleft$ : yeah>and we have some occasional tweets there $\triangleleft$ : yeah>it is something that $i$ have now [gradually gradually] $\triangleleft$ : [right yeah] yeah $>$ started to think whether it is of any [benefit] $\triangleleft$ : [yeah] yeah yeah>so we maybe have other kinds of channels if required we have like we try to cram our stuff in like this researchgate.net which is $\varangle$ : yeah $>$ where we put our publications so trying to make it more active $\varangle$ : yeah $>$ so that our publications would be available to other researchers and they are pretty easily found by googling and to some extent academia.edu but that is like we don't have the energy energy to update it like there are a bit too many holes that should should be kept [up-to-date] $\triangleleft:$ [(right yeah)]> so there too we are present to some extent but so things like these maybe we try to think about so because there are so many options [that which ones do we really have] $\triangleleft$ : [right right] exactly> the energy to use $((\ldots))$

(translated from Finnish)

What this example highlights is the multitude of options available in the world of social media and the limited resources researchers have to make use of all the potential there is. The promotional discourse evident also in the previous examples (5-7) is thus wrapped within discourses of usefulness and impact. The question then seems to be which channel, or rather which combination of channels to choose that supports the research group's aims best.

In all, the findings shed light on the role Twitter plays not only in individual researchers' but also, and perhaps in particular, in research groups' activities. Kuteeva (2016: 440) concludes her chapter on researchers' use of research blogs, wikis and tweets by writing that "Twitter is used to mediate the daily routines of scientific work and to keep researchers and collaborators connected, often at academic events". In my research interviews with the computer scientists, the role of Twitter in, for instance, conferences did not come up, but the text trajectory illustrates that it is used for that purpose as well: W3 tweeted a photo of W 1 presenting their co-authored paper. The social function of Twitter is thus evident in the data, even if the central function that emerges from the interviews and the tweets related to the example paper seems to be to share information about research activities in order to promote the visibility of the research group.

\section{Discussion and conclusion}


This paper has approached the use of digital writing and social media tools in research writing by focusing on the text trajectory of a collaboratively written research paper in the field of computer science, along with interviews with the main authors and their colleagues. The study looked at professional academics', rather than students' writing (see e.g. Bremner et al. 2014; papers in Van Steendam 2016), with particular focus on the writing of a research paper for publication and presentation at a prestigious conference. This traditional research writing genre still seems to hold a strong position in the field, as in academia more generally (see e.g. Belcher et al. 2016; Kuteeva 2016), which suggests that it is important to consider how writing in this genre may be changing due to technological advances (also consider the so called article of the future, see Pérez-Llantada 2013).

That the research paper writing was approached as a process, embedded in practices of the research group, made it possible to evaluate the use of digital tools not only for the actual writing of the paper but also along the trajectory of the text production. Various digital tools were used by the authors (and those they communicated with) not only to write the paper, but also to organise the writing in the research group more generally, as well as to communicate with those involved in the text production, and later to communicate about the results. What is notable, in the light of both of the research questions, is that digital tools played a central role both in the writing process and in what happened after the research paper was accepted and published. This means that while previous research has highlighted the importance for novice scholars to learn to navigate the writing-for-publication process (Li 2006), the text trajectory in this study draws attention to the importance of scholars' post-publication activities. The findings show that writing does not end when the research paper is finished, but rather changes form: the authors of the example text prepared a conference presentation ${ }^{6}$, tweeted, created website content and wrote a press release based on their paper.

The importance of Twitter, along with other social media, also became evident in the interview data, even if there was individual variation in how much, if at all, the study participants used social media for research purposes. For the most part, social media, with emphasis on Twitter, was described as important, and it seems that for some research groups (e.g. W3's group), it has become a central aspect of doing research. Finding the right 'eyes' for the work conducted in research groups, whether within academia or beyond, is what particularly some of the more senior scholars reported as the main reason for using social media. The findings also show that Twitter is used both for what could be expected and for what might not be expected; for instance, promoting the work of the research group might be expected, but sharing a link to the full paper before the conference presentation or using Twitter to keep up with the work of others might not.

The text trajectory also sheds light on what digital writing tools the researchers employed for the actual writing of the paper. In the example case, a real-time collaborative writing tool was used, and similar practices were also reported by the other interviewed researchers. While these new technologies enable new practices, particularly synchronous writing, it seems that the usability of such features is tied to particular activities or phases in the text production process (e.g. final revisions before submission). Different forms of parallel writing seemed to prevail, even if no specific writing strategy as suggested in Lowry et al.'s (2004) taxonomy of writing could be found.

The findings have important implications for researcher education. Social media can at least potentially increase the visibility for one's research, but it is central to find those channels that relevant stakeholders also use. By utilising social media, researchers have the opportunity to present their research in the way they want to present it; that is, they can promote their research on their own terms - at least initially. Based on my findings, individual researchers also seem to benefit from being part of research groups' social media activities and research groups seem to benefit from social-media-active individuals, because this increases the overall visibility of the work conducted in the group. The question for researcher education is how to prepare novice scholars not only for the multifaceted process of writing for publication but also for the process of writing for post-publication.

\footnotetext{
${ }^{6}$ In this case, it could also be argued that the conference presentation was the ultimate goal as the acceptance of the paper for the conference was a prerequisite for giving a talk at the conference.
} 


\section{Acknowledgements}

This work was conducted in the LaRA project, which is financially supported by the Kone Foundation [grant number 088787]. M y thanks to the study participants, who by sharing their time and experiences made this work possible, as well as to the editors of the special issue, Maria Kuteeva and Anna Mauranen, and the two anonymous reviewers for their valuable comments on earlier versions of this paper.

\section{References}

Armstrong, T., 2015. Peer feedback in disciplinary writing for publication in English: The case of 'Rolli', a German-L1 novice scholar. Journal of Academic W riting 5 (1), 86- 105.

Barton, D., 2007 Literacy: An introduction to the ecology of written language. 2nd ed. Oxford: Blackwell.

Barton, D., 2015. How the digital world is changing academics' writing lives. Invited Keynote Plenary paper at Digital Humanities conference, Open University of Hong Kong (December 2015).

Barton, D. \& Lee, C., 2013. Language online. London: Routledge.

Belcher, D. D., Barron Serrano, F. H. \& Yang, H. S., 2016. English for professional academic purposes. In: P. Shaw, \& K. Hyland (Eds.) The Routledge handbook of English for academic purposes. Abingdon, Oxon: Routledge.

Bremner, S., Pierson-Smith, A., Jones, R., \& Bhatia, V., 2014. Task design and interaction in collaborative writing: The students' story. Business and Professional Communication Quarterly 77(2), 150-168.

Ede, L., \& Lunsford, A., 1990. Singular texts/plural authors: Perspectives on collaborative writing. Carbondale: Southern Illinois University Press.

Ede, L., \& Lunsford, A., 2012. W riting together. Collaboration in theory and practice. Boston: Bedford / St. Martin's.

Flowerdew, J., 2001. Attitudes of journal editors to nonnative speaker contributions. TESOL Quarterly 35 (1), 121-150.

Flowerdew, J., 2008. Scholarly writers who use English as an Additional Language: What can Goffman's "Stigma" tell us? Journal of English for Academic Purposes 7, 77-86.

Forman, J., 1992 (Ed.). New visions of collaborative writing. Portsmouth, NH: Boynton/Cook.

Fransman, J., 2013. Researching academic literacy practices around Twitter. Performative methods and their onto-ethnical implications. In: R. Goodfellow \& M. R. Lea (Eds.) Literacy in the digital university. Critical perspectives on learning, scholarship, and technology. London: Routledge, pp. 27-41.

Gere, A. R., 1987. Writing groups: History, theory, implications. Carbondale: Southern Illinois University.

Gillen, J. \& M erchant, G., 2013. Contact calls: Twitter as a dialogic social and linguistic practice. Language Sciences 35, 47-58.

Gimenez, J. \& Thondhlana, J., 2012. Collaborative writing in engineering: Perspectives from research and implications for undergraduate education. European Journal of Engineering Education 37 (5), 471487.

Klein, P., 2015. M ediators and moderators in individual and collaborative writing to learn. Journal of W riting Research 7 (1), 201-214.

Kuteeva, M., 2016. Research blogs, wikis, and tweets. In: P. Shaw, \& K. Hyland (Eds.) The Routledge handbook of English for academic purposes. Abingdon, Oxon: Routledge. 431-443.

$\mathrm{Li}$, Y., 2006. A doctoral student of physics writing for publication: A sociopolitically-oriented case study. English for Specific Purposes 25, 456-478.

Lillis, T. 2008. Ethnography as method, methodology, and "deep theorizing". Closing the gap between text and context in academic writing research. Written Communication 25 (3), 353-388.

Lillis, T., 2013. The sociolinguistics of writing. Edinburgh: Edinburgh University Press.

Lillis, T. \& Curry, M. J., 2010. Academic writing in a global context. The politics and practices of publishing in English. London: Routledge.

Lillis, T. \& Curry, M. J., 2015. The politics of English, language and uptake. The case of international academic journal article reviews. AILA Review 28, 127-150. 
Lin, L. \& Evans, S., 2012. Structural patterns in empirical research articles: A cross-disciplinary study. English for Specific Purposes 31, 150-160.

Lillis, T. \& M cKinney, C., 2013. The sociolinguistics of writing in a global context: Objects, lenses, consequences. Journal of Sociolinguistics 17 (4), 415-439.

Lowry, P. B., Curtis, A. \& Lowry, M. R., 2004. Building a taxonomy and nomenclature of collaborative writing to improve interdisciplinary research and practice. Journal of Business Communication 41, 66-99.

M auranen, A., 2012. Exploring ELF. Academic English shaped by non-native speakers. Cambridge: Cambridge University Press.

M auranen, A., 2013. Hybridism, edutainment, and doubt: Science blogging finding its feet. Nordic Journal of English Studies 13 (1), 7-36.

M cGrath, L., 2013. Open-access writing: An investigation into the online drafting and revision of a research article in pure mathematics. English for Specific Purposes 43, 25-36.

M ur-Dueñas, P., 2013. Spanish scholars' research article publishing process in English-medium journals: English used as a lingua franca? J ournal of English as a Lingua Franca 2 (2), 315-340.

M yers, G., 2010. The discourse of blogs and wikis. London: Continuum.

M yers, G., 2013. Working and playing on science Twitter. Plenary paper at Twitter and M icroblogging: Political, Professional and Personal Practices conference, Lancaster University, 10-12 April 2013. http:// www.lancaster.ac.uk/ fass/ events/twitter_and_microblogging/video/GregM yers.htm.

Newman, J. \& Newman, R., 1992. Three modes of collaborative authoring. In P. L. Holt \& N.Williams (Eds.), Computers and writing: State of the art. Oxford, UK: Intellect Books, pp. 17-24.

Ochs, E. \& Jacoby, S., 1997. Down to the wire: The cultural clock of physicists and the discourse of consensus. Language in Society 26 (4), 479-505.

O’Donnell, A. M., Dansereau, D. F., Rocklin, T., Lambiotte, J. G., Hythecker, V. I., \& Larsen, C. O., 1985. Cooperative writing: Direct effects and transfer. Written Communication 2, 307-315.

Pérez-Llantada, C., 2013. The article of the future: Strategies for genre stability and change. English for Specific Purposes 32 (4), 221-235.

Puuska, H.-M . \& M iettinen, M ., 2008. Julkaisukäytännöt eri tieteenaloilla. [Publication practices in different disciplines] Opetusministeriön julkaisuja [Publications of the Finnish M inistry of Education] 2008: 33.

Samraj, B. , 2005. An exploration of a genre set: Research article abstracts and introductions in two disciplines. English for Specific Purposes 24, 141-156.

Scheliga, K., 2015. Collaborative writing in the context of science 2.0. i-KNOW '15, October 21-23, 2015.

Shehadeh, A., 2011. Effects and student perceptions of collaborative writing in L2. Journal of Second Language Writing 20, 286-305.

Storch, N., 2005. Collaborative writing: Product, process, and students' reflections. Journal of Second Language Writing 14 (3), 153-173.

Storch, N., 2013. Collaborative Writing in L2 Classrooms. Bristol, UK: Multilingual Matters.

Tusting, K., M cCulloch, S., \& Barton, D., 2017. The dynamics of knowledge creation: Academics' writing practices in the contemporary university workplace. Presentation at the Literacy Discussion Group, Lancaster University (28 Feb 2017). Slides available online:

https:// www.slideshare.net/SharonM cCulloch/Irdg-talk-by-tsuting-mcculloch-barton-28-feb-2017slides. (Accessed 10 June 2017).

Van Steendam, E., 2016. Editorial: Forms of collaboration in writing. Journal of Writing Research 8 (2), 183204.

Niina Hynninen is University Lecturer at the Department of Languages at the University of Helsinki. Her current research focuses on the writing practices of scholars in different disciplines, particularly from the perspective of how language is monitored and intervened in during the process of writing for publication. She has previously worked as a postdoc at the University of Helsinki and a lecturer at Stockholm University. She has published on topics related to academic discourse and English as a lingua franca, including a monograph with De Gruyter M outon (in 2016). 


\section{Supplementary materials}

\section{A. Transcription conventions}

Speaker codes:

$\begin{array}{ll}\text { I } & \text { Interviewer } \\ \text { C\# } & \text { Writer of the research paper in focus } \\ & \text { Colleague }\end{array}$

Transcription symbols:

te-

Unfinished utterances

(text)

Uncertain transcription

$(\mathrm{xx})$

Unintelligible speech

[text 1] [text 2]

Overlapping speech (approximate, shown to the nearest word, words not split by overlap tags)

$\triangleleft:$ text>

@@

@text@

$((.)$.

Backchannelling within angle brackets when marked within another speaker's turn

Brief pause (1-2 sec)

Laughter

Spoken laughter

Text omitted from transcription

\{text

Text added for clarity by writer of this paper

\section{B. Data extracts in Finnish}

The original Finnish-language data extracts below are numbered as in the article. Speaker codes are the same as in the paper (only without the ' $t$ ' indicating a translation).

\section{Unnumbered excerpts}

CS3: nää on nää perustyökalut joilla tehdään ens viikolla voi olla toiset

W1: me ollaan jaettu se linkki \{Overleaf-järjestelmässä olevaan käsikirjoitukseen\}tän meidän tutkijaporukan kesken ja on sovittu että mikä on kenenkin vastuualuetta ja sit siinä käydään tuottamassa tekstiä aina sovitusti

\section{Example 1}

W1: ((..)) kyl me sovittiin et kuka editoi millonkin $\triangleleft$ : just joo okei $>$ et paitsi ihan niinku sit lopussa viimesenä päivänä niin $\triangleleft$ : joo > siinä saatto olla et useampi $\varangle$ : joo>muokkas sitä samanaikasesti $\triangleleft$ : [joo]> [mut] siinäkin oli sovittu et kuka muokkaa mitäkin niinku et $\triangleleft$ : just> joku tekee taulukoita ja joku $\triangleleft$ : joo>oikolukee tekstiä

\section{Example 3}

W3: ((...)) tää on muuten hyvä mut tää on tota, sit jos joku tekee samanaikaisesti jotain niin sä oot nyt vaikka editoimas tässä ja joku on [tuol] ४: [joo]>yläpuolel niin sun teksti @ pomppii@ koko ajan alaspäin ४: aa [@okei@ okei] >[(joo) ni se] on ärsyttävää et et se samanaikaisuuden hallinta on semmonen [ongelma muuten tää on ihan tosi fiksu] $\triangleleft$ : [okei just joo joo joo]>mut se- senkin voi 
ratkaista niin et nää jakaa omiin tiedostoihin jokainen työskentelee omas tiedostossa $\triangleleft$ : aa>sit se on ok ४: okei just joo joo>

\section{Example 8}

W3: ((..)) et sanon nyt vaikka että jos mä pidän jonkun puheen $\varangle:$ joo> niin sit mä tietenkin ennen sitä puhetta mä kerron \{twitterissä\} että mä tuun pitämään sen puheen $\varangle:$ joo >ja nostan odotuksia ja sit mä pidän sen puheen sit samana hetkenä mä $\varangle$ : joo> julkaisen mun kalvot slidesharessa joka on kans ikään kuin [sosiaalista mediaa] $\triangleleft$ : [0kei joo]> sit mä saan ne inmiset kattoon sitä sitä niinku sadoittain [kattomaan et vaikkei ne 00 siel paikanpäällä ollu siel] $\triangleleft$ : [joo just joo] > puheessa ja tota samal tavalla kuin joku paperi tulee ulos niin sitä sit $\triangleleft$ : joo> julkaistaan aina aina niinku sosiaalises mediassa ja sitten $\varangle$ : joo>lehdistössä juttuja ja muuta et $\varangle$ : okei > se on tosi tärkee osa $\triangleleft$ : okei>tätä tätä työtä jos sitä ei tekis niin sit varmaan niinku huomio sille työlle olis [paljon pienempi ja sitten vaan tämmösen] $\triangleleft:$ : [mhm mhm mhm] > word of mouthin varassa $\varangle$ : joo joo > ja tietenkin niinkin niinkin voi mennä mut et sit siin on kaks aspektii toisaalta se et me saadaan se meidän työ niinku niitten ihmisten huomioon joiden pitääkin sitä katsoa mut sit toinen on semmonen et meil on tietysti yhteiskunnallinen vastuu et me ol- tehdään paljon semmosta työtä joka kiinnostaa ihmisiä $((\ldots))$

\section{Example 9}

C3: tää on vähän niinku se ajatus $\triangleleft:$ joo > ajatus tän niinku takana $\triangleleft$ : joo > et me saatais myös tarjottua sitä \{meidän tuotoksiamme \} ४: joo>jossain semmosessa paikassa paikassa tota mikä mikä nyt niinku ehkä löytäis nää $\triangleleft$ : nii justiin> jotkut yritysedustajat ((...)) nyt oikeestaan nytte ku perustettiin tän takia tää meidän oman ryhmän $\triangleleft:$ mhm-hm>twitter-tili niin $\triangleleft:$ joo> oli just et sit sinne tulee sit vaan sitä $\triangleleft$ : nii justiin $(x x)>$ tätä niinku tämmöstä ryhmään liittyvää $\triangleleft$ : joo> tavaraa ja siellä nyt niitä twiittejä on aika harvakseltaan $\triangleleft:$ joo> se on semmonen mitä mä nyt yritän tässä [pikkuhiljaa pikkuhiljaa] $\triangleleft$ : [nii joo] joo> miettiä että onks siitä jotain [iloa] $\triangleleft:$ [jo0] joo jo0> et enemmän ehkä meillä on sit toisenlaisia kanavia jos siihen nyt vaaditaan meillä on niinku mitä me mihin me yritetään tunkee sitten tavaraa on niinku tämmönen researchgate.net joka on semmonen $\triangleleft$ : $\mathrm{mhm}>$ mihin näitä julkasuja pistetään se et yrittäis saada se aktiiviseks $\triangleleft$ : joo> et jolloin ne julkasut tulis niinkun sen tutkijakunnan käyttöön ja löytyy googlella aika hyvin ja jonkun verran academia.edu mutta se on niinku sitä nyt ei jaksa jaksa ylläpitää niitä on vähän liian monta reikää mitä pitäis pitäis ylläpitää [koko ajan] $\triangleleft:[($ iin joo)] $>$ et sielläkin jonkun verran roikutaan mut siis niinku jotain tämmösiä ehkä yritetään sitte k- miettiä et ku se kirjo niin se on laaja [et mitä me niistä nyt oikeesti] <I: [niin niin] aivan> jaksetaan tehdä $((\ldots))$ 